\title{
Pengaruh Prinsip-Prinsip Good Corporate Governance pada Kinerja Keuangan Lembaga Perkreditan Desa
}

\author{
I Dewa Gede Dharma Suputra ${ }^{1}$ \\ Fakultas Ekonomi dan Bisnis \\ Universitas Udayana, Indonesia
}

\author{
Ni Luh Putu Hendrayanti ${ }^{2}$ \\ Fakultas Ekonomi dan Bisnis \\ Universitas Udayana, Indonesia
}

\begin{abstract}
Surel : hendrayanti39@gmail.com
ABSTRAK

Penelitian ini dilakukan di Lembaga Perkreditan Desa (LPD) Sekecamatan Kuta Utara, Kuta dan Kuta Selatan. Jumlah sampel yang diambil sebanyak 85 orang dengan Kepala dan Badan Pengawas LPD sebagai responden, dengan metode nonprobability sampling, khususnya sampling jenuh. Pengumpulan data dilakukan dengan teknik kuesioner. Teknik analisis yang dilakukan adalah regresi linear berganda. Berdasarkan hasil analisis ditemukan bahwa transparansi, akuntabilitas, responsibilitas, independensi dan kewajaran secara signifikan berpengaruh positif terhadap kinerja keuangan. Hal ini menunjukkan bahwa semakin transparan dalam menyajikan informasi, bertanggungjawab dalam pengelolaan LPD, mematuhi peraturan yang berlaku, independen serta wajar dan adil dalam memberikan tugas maka kinerja keuangan akan semakin meningkat.
\end{abstract}

Kata Kunci: Kinerja Keuangan; Transparansi; Akuntabilitas; Responsibilitas; Independensi; Kewajaran; LPD.

\section{The Effect of Good Corporate Governance Principles on Financial Performance of Village Credit Institutions}

\begin{abstract}
This research was conducted at the Village Credit Institution (LPD) in North Kuta, Kuta and South Kuta Districts. The number of samples taken was 85 people with the Head and the LPD Supervisory Board as respondents, using non-probability sampling methods, especially saturated sampling. Data collection is done by questionnaire technique. The analysis technique used is multiple linear regression. Based on the results of the analysis it was found that transparency, accountability, responsibility, independence and fairness had a significant positive effect on financial performance. This shows that the more transparent in presenting information, responsible for managing LPDs, complying with applicable regulations, independent and fair and fair in giving tasks, the financial performance will increase.
\end{abstract}

Keywords: $\quad$ Financial performance; Transparency; Accountability; Responsibility; Independence; Fairness; LPD.

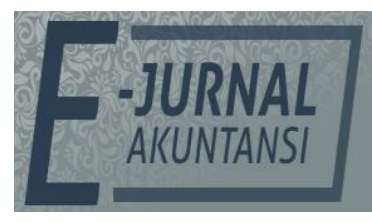

e-ISSN 2302-8556

Vol. 30 No. 9

Denpasar, September 2020

Hal. 2281-2295

DOI:

10.24843/EJA.2020.v30.i09.p09

PENGUTIPAN:

Suputra, I D. G. D. \&

Hendrayanti, N. L. P. (2020).

Pengaruh Prinsip-Prinsip

Good Corporate Governance pada Kinerja Keuangan

Lembaga Perkreditan Desa.

E-Jurnal Akuntansi, 30(9),

2281-2295

RIWAYAT ARTIKEL:

Artikel Masuk: 17 Mei 2020

Artikel Diterima: 19 Agustus 2020

Artikel dapat diakses : https://ojs.unud.ac.id/index.php/Akuntansi/index 


\section{PENDAHULUAN}

Di Indonesia lembaga keuangan dibagi menjadi 2 kelompok, yaitu lembaga keuangan bank dan lembaga keuangan non-bank. Di Bali terdapat lembaga keuangan non-bank yaitu Lembaga Perkreditan Desa (LPD). Menurut Peraturan Daerah Propinsi Bali Nomor 8 Tahun 2002 tentang LPD yaitu badan usaha keuangan milik Desa yang melaksanakan kegiatan usaha di lingkungan Desa dan untuk Krama Desa.

Tujuan dibentuknya LPD yakni untuk mendorong pembangunan ekonomi masyarakat Desa melalui kegiatan menghimpun tabungan dan deposito, serta menciptakan pemerataan kesempatan berusaha dan perluasan kesempatan kerja bagi Krama Desa. Selain itu, LPD dibentuk karena keberadaannya diharapkan untuk menjamin perwujudan kesejahteraan masyarakat desa (Muliartha RM, 2020).

Keberadaan LPD mengikuti jumlah desa adat di Bali. Daerah sekecamatan Kuta hingga Kuta Selatan merupakan wilayah pembangunan yang memiliki potensi dalam bidang pariwisata, bidang perdagangan, industri kecil, dan rumah tangga(Astawa et al., 2016) dan (Mandala et al., 2012). Sebagai daerah penyangga secara sosial ekonomi pasti memberikan dampak perubahan-perubahan baik dari segi fisik maupun sosial ekonomi. Untuk mengantisipasi adanya hal yang bersifat negatif akibat proses pembangunan, maka diperlukan adanya perangkat dan kelembagaan yang bersifat daerah yang mampu membantu masyarakat setempat dan diharapkan menjadi modal untuk menghadapi segala perubahan yang terjadi.

Pada tahun 2018, ketua LPD Kelan, Bendesa Adat Kelan serta mantan ketua LPD Kelan telah dilaporkan ke Polda Bali oleh owner PT Bukit Inn Resort dan Hotel Jimbaran View (balitribune). Hal ini dikarenakan mantan ketua LPD telah melakukan pemalsuan surat-surat dalam kapasitasnya sebagai ketua LPD Kelan tahun 2013 lalu. Beliau mengambil keputusan dan pencairan kredit sesuka hati, sehingga 75 debitur yang bernilai keseluruhan mencapai Rp 2,2 miliar berstatus macet (Suyatra, 2018). Beliau yang tidak mampu mengembalikan kerugian tersebut dalam kurun waktu enam bulan pun bertindak dengan membuat pinjaman ke LPD Kelan senilai Rp 2,9 miliar atas nama PT. Bukit Inn Resort. Sedangkan Bendesa adat dilaporkan karena memaksa mantan ketua LPD Kelan untuk mengaku uang yang telah dipinjam tersebut untuk PT. Bukit Inn Resort. Ketua LPD dilaporkan karena melaporkan pailit ke Pengadilan Niaga di Surabaya.

Pada tahun 2017, Bendesa adat telah salah mengeluarkan kebijakan yang tidak sesuai dengan tujuan LPD. Terjadi dua transaksi akibat salah kebijakan, diantaranya pemberian kredit kepada sebuah perusahaan taksi di Lombok serta investasi pembelian tanah di NTB, hal tersebut mengakibatkan kredit macet (nusabali).

Kasus tersebut mengindikasikan bahwa manajemen memiliki kesempatan untuk melakukan tindak kecurangan demi keuntungan pribadi serta melaksanakan proses pengambilan keputusan secara sepihak. Kasus yang terjadi adalah manajemen menutupi informasi yang sebenarnya sehingga informasi tersebut tidak relevan digunakan dalam pengambilan keputusan serta manajemen telah menyalahgunakan kekuasaan. Selain itu, kasus tersebut 
mengindikasikan bahwa terjadi konflik keagenan berupa asimetri informasi. Sehingga menyebabkan kerugian bagi masyarakat serta LPD tersebut. Oleh karena itu, hal ini menjadi topik yang menarik untuk diteliti, khususnya mengenai faktor-faktor yang mempengaruhi kinerja keuangan.

Berdasarkan Peraturan Menteri BUMN Nomor PER-01/MBU/2011 Good Corporate Governance (GCG) adalah prinsip-prinsip yang mendasari suatu proses dan mekanisme pengelolaan perusahaan berlandaskan peraturan perundangundangan dan etika berusaha. GCG adalah suatu tata kelola untuk mengendalikan dan mengarahkan aktivitas perusahaan (El-Chaarani, 2014). Penerapan GCG tersebut dibutuhkan untuk menciptakan pasar yang efisien, transparan, dan konsisten yang sesuai dengan perundang-undangan. Agar tujuan perusahaan dapat tercapai, prinsip-prinsip GCG yang terdapat dalam perusahaan akan memaksimalkan kinerja serta adanya kepercayaan dari para pemangku kepentingan dengan manajer (Hindistari dan Putri, 2016).

Prinsip GCG terdiri dari lima prinsip yang mendasari, yang terdiri dari transparansi, akuntabilitas, responsibilitas, independensi, dan kewajaran. Rambo (2013) menyatakan bahwa kelima prinsip tersebut diharapkan dapat menghasilkan keputusan yang lebih optimal dan jika tata kelola perusahaan baik, maka hal tersebut menunjukkan tanggungjawab perusahaan terpenuhi.

Pada fenomena yang terjadi di LPD, mengidentifikasi bahwa terdapat pelanggaran prinsip-prinsip GCG. Prinsip GCG yang dilanggar adalah prinsip akuntabilitas, karena tidak mampu mempertanggungjawabkan kinerjanya secara wajar dan transparan (Gupta et al., 2019). Adapun prinsip responsibilitas yang telah dilanggar, karena tidak mematuhi peraturan undang-undang atau peraturan daerah yang berlaku. Hal ini dikarenakan manajemen melakukan pelanggaran demi kepentingan diri sendiri tanpa berlandaskan tujuan LPD. Selain itu, adapun prinsip independensi yang telah di langgar, hal ini karena dalam pengambilan keputusan terjadi benturan kepentingan dan pengaruh dari pihak lain.

Hart (1995) menyatakan bahwa Corporate Governance muncul dalam organisasi disebabkan karena adanya masalah agensi atau konflik kepentingan yang melibatkan anggota organisasi. Pada teori keagenan, permasalahan agency muncul ketika pengelolaan suatu perusahaan terpisah dari kepemilikannya. Pemilik perusahaan mendelegasikan wewenangnya atas pengelolaan perusahaan kepada manajernya. Jensen \& Meckling (1976) menyatakan bahwa hubungan keagenan merupakan suatu kontrak yang terjadi diantara prinsipal dengan agen yang merupakan pengelola perusahaan. Akan tetapi, sebuah kontrak bukanlah jaminan bahwa manajer akan selalu mengutamakan kepentingan pemilik perusahaan (Devi \& Ratnadi, 2018). Untuk mendukung penerapan GCG, maka penerapan teori stewardship ini akan mendukung terlaksananya pelaksanaan GCG yang akan mendorong perusahaan agar tercipta sistem tata kelola perusahaan yang sehat. Hal ini dikarenakan berdasarkan teori stewardship, manajemen selalu bertindak sedemikian rupa untuk memaksimalkan kepentingan perusahaan dan lingkungan bisnis dan pencapaian GCG.

Pada penelitian ini, pihak pengelola LPD merupakan agen, sedangkan krama desa sebagai prinsipal. Pihak pengelola LPD merupakan pihak yang paling banyak memiliki informasi dibandingkan krama Desa Pakraman dan hal 
inilah yang menimbulkan asimetri informasi. Asimetri informasi adalah ketidaksetaraan informasi yang dimiliki antara pihak agen dan prinsipal. Salah satu cara untuk mengatasi asimetri informasi yaitu perlu memberikan perhatian pada lemahnya penerapan tata kelola perusahaan. Selain itu, dengan penerapan GCG akan berfungsi untuk menumbuhkan kepercayaan nasabah terhadap LPD itu sendiri agar tujuan dari organisasi dapat tercapai (Setyawan \& Putri, 2013).

Gayatri \& Suputra (2013) menyatakan bahwa unsur Corporate Governance terdapat dalam laporan keuangan yang merupakan sebuah rangkaian tentang sebuah proses, kebiasaan, kebijakan, aturan, dan institusi yang mempengaruhi pengarahan, pengelolaan, serta pengontrolan suatu perusahaan atau korporasi. GCG diduga mempunyai pengaruh yang kuat dalam memperbaiki kinerja perusahaan (Korompis \& Wirajaya, 2017). Sehingga penerapan GCG yang baik dapat berpengaruh pada profitabilitas perusahaan (Bistrova \& Lace, 2012).

Berdasarkan teori keagenan yaitu agen lebih banyak mengetahui tentang informasi perusahaan, maka untuk menghindari asimetri informasi diperlukan keterbukaan informasi (Devi \& Ratnadi, 2018). Keterbukaan untuk memberikan informasi terhadap pihak yang berkepentingan akan menambah kepercayaan stakeholder.

Berdasarkan penelitian Sandraningsih \& Putri (2015) yang menyatakan bahwa transparansi berpengaruh positif terhadap kinerja keuangan LPD Kecamatan Abiansemal Kabupaten Badung. Hal tersebut juga terjadi pada penelitian yang dilakukan oleh Andreana \& Wirajaya (2018), transparansi berpengaruh positif terhadap kinerja keuangan LPD di Kabupaten Klungkung.

Semakin transparan LPD dalam mengungkapkan informasi yang material dan relevan mengenai keadaan LPD akan mengakibatkan peningkatan kepercayaan prinsipal, maka kinerja keuangan akan meningkat. Berdasarkan uraian tersebut maka rumusan hipotesis pertama dalam penelitian ini sebagai berikut.

$\mathrm{H}_{1}$ : Prinsip transparansi berpengaruh positif pada kinerja keuangan LPD di Kecamatan Kuta Utara, Kuta dan Kuta Selatan.

Sejalan dengan teori keagenan, semakin jelas struktur, fungsi serta wewenang dalam perusahaan, maka operasional perusahaan akan semakin terarah dan efisien. Hal ini dikarenakan akuntabilitas adalah prasyarat yang diperlukan untuk mencapai kinerja yang berkesinambungan. Akuntabilitas adalah kewajiban untuk memberikan pertanggungjawaban serta untuk menjawab dan menerangkan kinerja dan tindakan manajemen perusahaan kepada pihak yang memiliki hak atau wewenang untuk meminta pertanggungjawaban.

Berdasarkan penelitian Sandraningsih \& Putri (2015) yang menyatakan bahwa akuntabilitas berpengaruh positif terhadap kinerja keuangan LPD Kecamatan Abiansemal Kabupaten Badung. Hal tersebut juga terjadi pada penelitian Andreana \& Wirajaya (2018), akuntabilitas berpengaruh positif terhadap kinerja keuangan LPD di Kabupaten Klungkung.

Semakin jelas struktur, fungsi dan wewenang pelaksanaan dalam LPD maka pengelolaan LPD akan terlaksana dengan efektif dan efisien serta akan meningkatkan kepercayaan prinsipal, sehingga kinerja keuangan akan 
meningkat. Berdasarkan uraian tersebut maka rumusan hipotesis kedua dalam penelitian ini ini sebagai berikut.

$\mathrm{H}_{2}$ : Prinsip akuntabilitas berpengaruh positif pada kinerja keuangan LPD di Kecamatan Kuta Utara, Kuta dan Kuta Selatan.

Prinsip responsibilitas menekankan perusahaan harus berpegang pada hukum yang berlaku dan dapat mempertanggungjawabkan semua kegiatan perusahaan pada stakeholder dan masyarakat. Berdasarkan teori stewardship yang menggambarkan para manajer tidak termotivasi oleh tujuan-tujuan individu tetapi lebih merujuk kepada sasaran hasil utama demi kepentingan organisasi (Riyadi \& Yulianto, 2014).

Berdasarkan penelitian Sandraningsih \& Putri (2015) yang menyatakan bahwa responsibilitas berpengaruh positif terhadap kinerja keuangan LPD Kecamatan Abiansemal Kabupaten Badung. Hal tersebut juga terjadi pada penelitian Andreana \& Wirajaya (2018), responsibilitas berpengaruh positif terhadap kinerja keuangan LPD di Kabupaten Klungkung.

Sejalan dengan teori stewardship, bahwa agen dapat bertindak sesuai dengan keinginan prinsipal untuk mencapai tujuan LPD, sehingga dikatakan bahwa agen mematuhi dan bertanggungjawab atas peraturan LPD demi mencapai tujuan bersama, maka dari itu akan meningkatkan kinerja keuangan. Berdasarkan uraian tersebut maka rumusan hipotesis ketiga dalam penelitian ini sebagai berikut.

$\mathrm{H}_{3}$ : Prinsip responsibilitas berpengaruh positif pada kinerja keuangan LPD di Kecamatan Kuta Utara, Kuta dan Kuta Selatan.

Berdasarkan teori keagenan, perbedaan kepentingan antara agen dan prinsipal akan menimbulkan adanya asimetri informasi. Hal ini dapat diminimalisir jika agen independen terhadap tanggungjawabnya dengan tidak mudah terpengaruh oleh pihak lain. Andreana \& Wirajaya (2018) menyatakan bahwa, jika perusahaan independen dan tidak terpengaruh oleh pihak lain, maka perusahaan akan terhindar dari pihak-pihak yang dapat merugikan perusahaan, sehingga kinerja keuangan perusahaan semakin baik.

Berdasarkan penelitian Sandraningsih \& Putri (2015) yang menyatakan bahwa independensi berpengaruh positif terhadap kinerja keuangan LPD Kecamatan Abiansemal Kabupaten Badung. Hal tersebut juga terjadi pada penelitian Andreana \& Wirajaya (2018), independensi berpengaruh positif terhadap kinerja keuangan LPD di Kabupaten Klungkung.

Dengan tidak adanya benturan kepentingan dalam pengelolaan LPD dapat berdampak pada meningkatnya kepercayaan prinsipal, sehingga kinerja keuangan akan meningkat. Berdasarkan uraian tersebut maka rumusan hipotesis keempat dalam penelitian ini ini sebagai berikut.

$\mathrm{H}_{4}$ : Prinsip independensi berpengaruh positif pada kinerja keuangan LPD di

Kecamatan Kuta Utara, Kuta dan Kuta Selatan.

Berdasarkan teori keagenan, prinsipal sebagai pemilik akan memberi perintah kepada agen, dalam hal ini prinsipal harus mampu memperlakukan agen dengan setara dan wajar agar agen menyampaikan informasi perusahaan secara benar dan sesuai dengan kondisi perusahaan sehingga tidak terjadi asimetri informasi. Kewajaran dapat pula diartikan sebagai keadilan perusahaan 
dalam memenuhi kepentingan stakeholders berdasarkan undang-undang yang berlaku (Sandraningsih \& Putri, 2015).

Berdasarkan penelitian Sandraningsih \& Putri (2015) yang menyatakan bahwa kewajaran berpengaruh positif terhadap kinerja keuangan LPD Kecamatan Abiansemal Kabupaten Badung. Hal tersebut juga terjadi pada penelitian Andreana \& Wirajaya (2018), kewajaran berpengaruh positif terhadap kinerja keuangan LPD di Kabupaten Klungkung.

Apabila pengelola LPD memperhatikan hak dari prinsipal serta memperlakukan secara adil berdasarkan asas kewajaran maka dapat meningkatkan kepercayaan prinsipal, sehingga kinerja keuangan akan meningkat. Berdasarkan uraian tersebut maka rumusan hipotesis kelima dalam penelitian ini ini sebagai berikut.

$\mathrm{H}_{5}$ : Prinsip kewajaran berpengaruh positif pada kinerja keuangan LPD di Kecamatan Kuta Utara, Kuta dan Kuta Selatan.

\section{METODE PENELITIAN}

Penelitian ini dilakukan pada LPD yang berada di Kecamatan Kuta Utara, Kuta dan Kuta Selatan dengan memberikan kuesioner dan mencari laporan keuangan tahun 2015 hingga 2018 pada LPD yang dijadikan sampel penelitian di LPLPD Kabupaten Badung. Objek dalam penelitian ini adalah kinerja keuangan tahun 2015 hingga 2018 yang dipengaruhi oleh transparansi, akuntabilitas, responsibilitas, independensi, dan kewajaran pada LPD Kecamatan Kuta Utara, Kuta dan Kuta Selatan.

Populasi dalam penelitian ini adalah seluruh LPD yang berada di Kecamatan Kuta Utara, Kuta dan Kuta Selatan. Jumlah LPD yang berada di Kecamatan Kuta Utara, Kuta dan Kuta Selatan adalah 23 LPD. Metode pengambilan sampel dalam penelitian ini menggunakan metode sampling jenuh. Sampling jenuh adalah sampel yang bila ditambah jumlahnya, tidak akan menambah keterwakilan sehingga tidak akan mempengaruhi nilai informasi yang telah diperoleh. Responden yang dipilih dalam penelitian ini adalah orangorang yang mengetahui wewenang dan tugas pengelolaan LPD dan fungsifungsi badan pengawas dalam menilai peranan GCG terhadap kinerja keuangan. Responden tiap-tiap LPD yang diambil yaitu kepala LPD dan badan pengawas sehingga total responden berjumlah 85 orang.

Hipotesis penelitian ini diuji dengan analisis regresi linear berganda dengan menggunakan statistical product and service solutions (SPSS). Hasil anaisis dinyatakan dalam bentuk persamaan regresi linear sebagai berikut.

$Y=a+\beta_{1} X_{1}+\beta_{2} X_{2}+\beta_{3} X_{3}+\beta_{4} X_{4}+\beta_{5} X_{5}+\varepsilon$

Keterangan:

$\mathrm{Y} \quad=$ Variabel terikat (Kinerja Keuangan)

a $\quad=$ Konstanta

$\beta_{1}, \beta_{2}, \beta_{3}, \beta_{4}, \beta_{5}=$ Koefisien regresi untuk $X_{1}, X_{2}, X_{3}, X_{4}, X_{5}$

$X_{1}=$ Variabel bebas (Transparansi)

$\mathrm{X}_{2} \quad=$ Variabel bebas (Akuntabilitas)

$\mathrm{X}_{3} \quad=$ Variabel bebas (Responsibilitas)

$\mathrm{X}_{4} \quad=$ Variabel bebas (Independensi)

$\mathrm{X}_{5} \quad=$ Variabel bebas (Kewajaran) 
Ketepatan fungsi regresi sampel dalam menaksir nilai aktual yang dapat diukur dengan melihat nilai Adjusted $\mathrm{R}^{2}$ dalam uji koefisien determinasi dan nilai F dalam uji kelayakan model.

\section{HASIL DAN PEMBAHASAN}

Statistik deskriptif digunakan untuk memberikan gambaran atau deskriptif suatu data yang dilihat dari nilai rata-rata (mean), nilai minimum, nilai maksimum, dan nilai dari data penelitian. Hasil dari pengujian statistik deskriptif dari masing-masing variabel penelitian disajikan pada Tabel 1.

\section{Tabel 1. Hasil Uji Statistik Deskriptif}

\begin{tabular}{llllll}
\hline Variabel & $\mathrm{N}$ & Minimum & Maksimum & Mean & $\begin{array}{l}\text { Std. } \\
\text { Deviation }\end{array}$ \\
\hline Transparansi & 85 & 10 & 20 & 15,88 & 2,422 \\
Akuntabilitas & 85 & 19 & 30 & 25,45 & 2,938 \\
Responsibilitas & 85 & 10 & 20 & 15,94 & 2,311 \\
Independensi & 85 & 12 & 20 & 16,36 & 1,863 \\
Kewajaran & 85 & 8 & 15 & 11,76 & 1,702 \\
\hline
\end{tabular}

Sumber: Data Penelitian, 2020

Berdasarkan Tabel 1, total sampel yang digunakan adalah 85. Variabel transparansi memiliki nilai minimum sebesar 10 dan nilai maksimum sebesar 20 . Variabel transparansi yang diukur dengan 4 item pernyataan dengan bantuan skala likert 5 poin memiliki rata-rata sebesar 15,88. Nilai standar deviasi variabel transparansi sebesar 2,422. Nilai ini lebih rendah dibandingkan dengan nilai ratarata. Hal ini menunjukkan bahwa sebaran data berupa jawaban responden pada butir-butir pernyataan transparansi dapat dinyatakan sudah merata atau rentang data satu dengan yang lainnya tidak tergolong tinggi.

Berdasarkan Tabel 1, total sampel yang digunakan adalah 85. Variabel akuntabilitas memiliki nilai minimum sebesar 19 dan nilai maksimum sebesar 30 . Variabel akuntabilitas yang diukur dengan 6 item pernyataan dengan bantuan skala likert 5 poin memiliki rata-rata sebesar 25,45. Nilai standar deviasi variabel akuntabilitas sebesar 2,938. Nilai ini lebih rendah dibandingkan dengan nilai rata-rata. Hal ini menunjukkan bahwa sebaran data berupa jawaban responden pada butir-butir pernyataan akuntabilitas dapat dinyatakan sudah merata atau rentang data satu dengan yang lainnya tidak tergolong tinggi.

Berdasarkan Tabel 1, total sampel yang digunakan adalah 85. Variabel responsibilitas memiliki nilai minimum sebesar 10 dan nilai maksimum sebesar 20. Variabel responsibilitas yang diukur dengan 4 item pernyataan dengan bantuan skala likert 5 poin memiliki rata-rata sebesar 15,94. Nilai standar deviasi variabel responsibilitas sebesar 2,311. Nilai ini lebih rendah dibandingkan dengan nilai rata-rata. Hal ini menunjukkan bahwa sebaran data berupa jawaban responden pada butir-butir pernyataan responsibilitas dapat dinyatakan sudah merata atau rentang data satu dengan yang lainnya tidak tergolong tinggi.

Berdasarkan Tabel 1, total sampel yang digunakan adalah 85. Variabel independensi memiliki nilai minimum sebesar 12 dan nilai maksimum sebesar 20. Variabel independensi yang diukur dengan 4 item pernyataan dengan bantuan skala likert 5 poin memiliki rata-rata sebesar 16,36. Nilai standar deviasi variabel independensi sebesar 1,863. Nilai ini lebih rendah dibandingkan dengan 
nilai rata-rata. Hal ini menunjukkan bahwa sebaran data berupa jawaban responden pada butir-butir pernyataan independensi dapat dinyatakan sudah merata atau rentang data satu dengan yang lainnya tidak tergolong tinggi.

Berdasarkan Tabel 1, total sampel yang digunakan adalah 85. Variabel kewajaran memiliki nilai minimum sebesar 8 dan nilai maksimum sebesar 15 . Variabel kewajaran yang diukur dengan 3 item pernyataan dengan bantuan skala likert 5 poin memiliki rata-rata sebesar 11,76. Nilai standar deviasi variabel kewajaran sebesar 1,702. Nilai ini lebih rendah dibandingkan dengan nilai ratarata. Hal ini menunjukkan bahwa sebaran data berupa jawaban responden pada butir-butir pernyataan kewajaran dapat dinyatakan sudah merata atau rentang data satu dengan yang lainnya tidak tergolong tinggi.

Variabel kinerja keuangan dalam penelitian ini merupakan variabel terikat yang dianalisis nilai maksimum, minimum, rata-rata, dan standar deviasinya. Adapun hasil analisis disajikan pada Table 2.

Tabel 2. Deskripsi Nilai Kinerja Keuangan

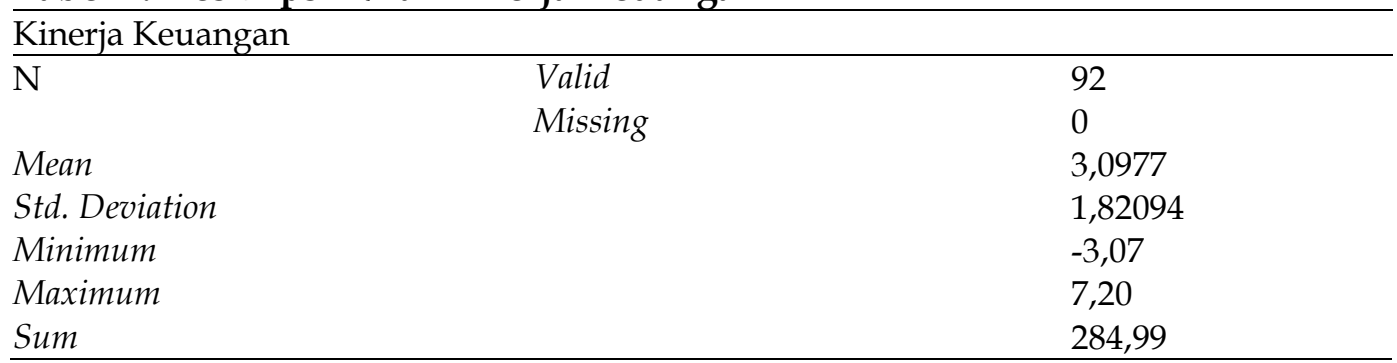

Sumber: Data Penelitian, 2020

Tabel 2, menunjukkan hasil analisis mengenai variabel kinerja keuangan. Nilai minimumnya adalah $-3,07$, nilai maksimumnya adalah 7,20 , nilai rataratanya adalah 3,0977, dan standar deviasinya adalah 1,82094. Karena nilai standar deviasi kurang dari rata-rata maka penyebaran data dalam kriteria baik.

Teknik analisis ini digunakan untuk mengetahui seberapa besar pengaruh variabel bebas yaitu, Transparansi $\left(X_{1}\right)$, Akuntabilitas $\left(X_{2}\right)$, Responsibilitas $\left(X_{3}\right)$, Independensi $\left(X_{4}\right)$, dan Kewajaran $\left(X_{5}\right)$ terhadap variabel terikatnya yaitu Kinerja Keuangan $(Y)$.

Tabel 3. Hasil Analisis Regresi Linier Berganda

\begin{tabular}{|c|c|c|c|c|c|}
\hline \multirow[b]{2}{*}{ Model } & \multicolumn{2}{|c|}{$\begin{array}{l}\text { Unstandardized } \\
\text { Coefficients }\end{array}$} & \multicolumn{2}{|l|}{$\begin{array}{l}\text { Standardized } \\
\text { Coefficients }\end{array}$} & \multirow[b]{2}{*}{ Sig. } \\
\hline & $\bar{B}$ & Std. Error & Beta & $\mathrm{t}$ & \\
\hline 1 (Constant) & $-9,619$ & ,707 & & $-13,601$ & ,000 \\
\hline Transparansi & 148 & ,071 & 210 & 2,085 & 040 \\
\hline Akuntabilitas & 110 & ,049 & 190 & 2,259 & ,027 \\
\hline Responsibilitas & 132 & ,062 & 179 & 2,112 & ,038 \\
\hline Independensi & 203 & ,090 & 222 & 2,247 & ,027 \\
\hline Kewajaran & 205 & ,090 & 205 & 2,276 & ,026 \\
\hline
\end{tabular}

Sumber: Data Penelitian, 2020 berikut:

Berdasarkan Tabel 3, dapat dibuat persamaan regresi linier berganda

$$
Y=-9,619+0,148 X_{1}+0,110 X_{2}+0,132 X_{3}+0,203 X_{4}+0,205 X_{5}+\varepsilon
$$


Konstanta (a) sebesar $-9,619$ memiliki arti apabila transparansi, akuntabilitas, responsibilitas, independensi, dan kewajaran memiliki nilai konstan pada angka nol maka nilai kinerja keuangan akan bernilai sebesar -9,619.

Koefisien regresi variabel transparansi sebesar 0,148 bernilai positif memiliki arti apabila akuntabilitas, responsibilitas, independensi, dan kewajaran bernilai 1 satuan maka kinerja keuangan akan semakin meningkat sebesar 0,148 dengan asumsi variabel lainnya konstan pada angka nol.

Koefisien regresi variabel akuntabilitas sebesar 0,110 bernilai positif memiliki arti apabila transparansi, responsibilitas, independensi, dan kewajaran bernilai 1 satuan maka kinerja keuangan akan meningkat sebesar 0,110 dengan asumsi variabel lainnya konstan pada angka nol.

Koefisien regresi variabel responsibilitas sebesar 0,132 bernilai positif memiliki arti apabila transparansi, akuntabilitas, independensi, dan kewajaran bernilai 1 satuan maka kinerja keuangan akan meningkat sebesar 0,132 dengan asumsi variabel lainnya konstan pada angka nol.

Koefisien regresi variabel independensi sebesar 0,203 bernilai positif memiliki arti apabila transparansi, akuntabilitas, responsibilitas, dan kewajaran bernilai 1 satuan maka kinerja keuangan akan meningkat sebesar 0,203 dengan asumsi variabel lainnya konstan pada angka nol.

Koefisien regresi variabel kewajaran sebesar 0,205 bernilai positif memiliki arti apabila transparansi, akuntabilitas, responsibilitas, dan independensi bernilai 1 satuan maka kinerja keuangan akan meningkat sebesar 0,205 dengan asumsi variabel lainnya konstan pada angka nol.

Menguji signifikansi variabel bebas transparansi (X1), akuntabilitas (X2), responsibilitas (X3), independensi (X4), dan kewajaran (X5) secara serempak terhadap variabel terikat kinerja keuangan(Y).

\section{Tabel 4. Hasil Uji F-test}

\begin{tabular}{|c|c|c|c|c|c|c|}
\hline \multicolumn{2}{|c|}{ Model } & \multicolumn{2}{|c|}{ Sum of Squares $\mathrm{df}$} & \multirow{2}{*}{$\begin{array}{l}\text { Mean Square } \\
41,586\end{array}$} & \multirow{2}{*}{$\begin{array}{l}\mathrm{F} \\
92,356\end{array}$} & \multirow{2}{*}{$\frac{\text { Sig. }}{, 000^{\mathrm{b}}}$} \\
\hline$\overline{1}$ & Regression & 207,928 & 5 & & & \\
\hline & Residual & 35,572 & 79 & 450 & & \\
\hline & Total & 243,500 & 84 & & & \\
\hline
\end{tabular}

a. Dependent Variable: Kinerja Keuangan

b. Predictors: (Constant), Kewajaran, Responsibilitas, Akuntabilitas, Independensi, Transparansi

Sumber: Data Penelitian, 2020

Berdasarkan Tabel 4, hasil uji signifikansi simultan (Uji F) diperoleh nilai signifikansi $\mathrm{F}$ sebesar 0,000. Nilai signifikan 0,000 $<0,05$ mempunyai arti bahwa transparansi, akuntabilitas, responsibilitas, independensi, dan kewajaran diduga secara signifikan berpengaruh dengan kinerja keuangan.

Koefisien determinasi (R2) berguna untuk mengukur besarnya kontribusi variabel bebas (transparansi, akuntabilitas, responsibilitas, independensi, dan kewajaran) terhadap variabel terikat (kinerja keuangan). Pengujian koefisien determinasi pada penelitian ini akan menggunakan bantuan program SPSS. 
Tabel 5. Hasil Analisis Koefisien Determinasi

\begin{tabular}{lllllr}
\hline Model & $\mathrm{R}$ & $\mathrm{R}$ Square & Adjusted R Square & $\begin{array}{l}\text { Std. Error of the } \\
\text { Estimate }\end{array}$ & \\
\hline 1 &, $924^{\mathrm{a}}$ &, 854 &, 845 &, 67102 & \\
\hline
\end{tabular}

Sumber: Data Penelitian, 2020

Berdasarkan Tabel 5, dapat diamati nilai adjusted $\mathrm{R}^{2}$ sebesar 0,845 berarti $84,5 \%$ perubahan (naik turun) pada Kinerja keuangan yang dipengaruhi oleh transparansi, akuntabilitas, responsibilitas, independensi, dan kewajaran, sementara sisanya sejumlah $15,5 \%$ dipengaruhi oleh faktor-faktor lain diluar penelitian ini.

Pengujian secara parsial bertujuan menguji signifikan pengaruh variabel bebas (transparansi, akuntabilitas, responsibilitas, independensi, dan kewajaran terhadap variabel terikat kinerja keuangan.

Tabel 6. Hasil Uji t-test

\begin{tabular}{|c|c|c|c|c|c|}
\hline \multirow[b]{2}{*}{ Model } & \multicolumn{2}{|c|}{$\begin{array}{l}\text { Unstandardized } \\
\text { Coefficients }\end{array}$} & \multirow{2}{*}{$\begin{array}{l}\text { Standardized } \\
\text { Coefficients } \\
\text { Beta }\end{array}$} & \multirow[b]{2}{*}{$\mathrm{t}$} & \multirow[b]{2}{*}{ Sig. } \\
\hline & $\mathrm{B}$ & Std. Error & & & \\
\hline 1 (Constant) & $-9,619$ & 707 & & $-13,601$ & 000 \\
\hline Transparansi & 148 & ,071 & ,210 & 2,085 & ,040 \\
\hline Akuntabilitas & 110 & ,049 & 190 & 2,259 & 027 \\
\hline Responsibilitas & 132 & ,062 & 179 & 2,112 & ,038 \\
\hline Independensi & 203 & ,090 & ,222 & 2,247 & ,027 \\
\hline Kewajaran & 205 & ,090 & 205 & 2,276 & ,026 \\
\hline
\end{tabular}

a. Dependent Variable: Kinerja Keuangan

Sumber: Data Penelitian, 2020

Berdasarkan hasil uji $\mathrm{t}$ pengaruh transparansi terhadap kinerja keuangan diperoleh nilai signifikansi sebesar 0,040 dengan nilai koefisien regresi sebesar 0,148 bernilai positif. Nilai signifikansi 0,040 < 0,05 mengindikasikan bahwa $\mathrm{H}_{1}$ diterima. Hasil ini mempunyai arti bahwa transparansi diduga secara signifikan berpengaruh positif dengan kinerja keuangan. Hal ini berarti jika transparansi semakin baik, maka kinerja keuangan semakin baik, sebaliknya jika transparansi semakin buruk maka kinerja keuangan akan semakin buruk pula.

Transparansi adalah keterbukaan dalam melaksanakan suatu proses kegiatan perusahaan. Mengetahui seluruh informasi secara benar dan terbuka dalam pengelolaan sumber daya merupakan salah satu hak stakeholders, ini berarti transparan terhadap seluruh informasi harus diterapkan agen guna memberikan kepercayaan bagi stakeholders (Sandraningsih dan Putri, 2015).

Dalam penelitian Devi \& Ratnadi (2018) berdasarkan teori keagenan yaitu agen lebih banyak mengetahui tentang informasi perusahaan, maka untuk menghindari asimetri informasi diperlukan keterbukaan informasi. Keterbukaan untuk memberikan informasi terhadap pihak yang berkepentingan akan menambah kepercayaan stakeholder sehingga dapat meningkatkan kinerja keuangan.

Berdasarkan penelitian Sandraningsih \& Putri (2015) yang menyatakan bahwa transparansi berpengaruh positif terhadap kinerja keuangan LPD Kecamatan Abiansemal Kabupaten Badung. Hal tersebut juga terjadi pada penelitian yang dilakukan oleh Andreana \& Wirajaya (2018), transparansi berpengaruh positif terhadap kinerja keuangan LPD di Kabupaten Klungkung. 
Berdasarkan Tabel 6, hasil uji $\mathrm{t}$ pengaruh kewajaran terhadap kinerja keuangan diperoleh nilai signifikansi sebesar 0,026 dengan nilai koefisien regresi sebesar 0,205 bernilai positif. Nilai signifikansi 0,026 $<0,05$ mengindikasikan bahwa $\mathrm{H}_{1}$ diterima. Hasil ini mempunyai arti bahwa kewajaran diduga secara signifikan berpengaruh positif pada kinerja keuangan.

Penelitian ini memberikan hasil bahwa transparansi berpengaruh positif pada kinerja keuangan LPD di Kecamatan Kuta Utara, Kuta dan Kuta Selatan. Artinya, semakin transparan LPD dalam mengungkapkan informasi yang material dan relevan mengenai keadaan LPD, maka semakin meningkat pula kinerja keuangan LPD.

Transparansi adalah keterbukaan dalam melaksanakan suatu proses kegiatan perusahaan. Mengetahui seluruh informasi secara benar dan terbuka dalam pengelolaan sumber daya merupakan salah satu hak stakeholders, ini berarti transparan terhadap seluruh informasi harus diterapkan agen guna memberikan kepercayaan bagi stakeholders (Sandraningsih \& Putri, 2015).

Berdasarkan penelitian Sandraningsih \& Putri (2015) yang menyatakan bahwa transparansi berpengaruh positif dan signifikan terhadap kinerja keuangan LPD Kecamatan Abiansemal Kabupaten Badung. Hal tersebut juga terjadi pada penelitian yang dilakukan oleh Andreana \& Wirajaya (2018), transparansi berpengaruh positif dan signifikan terhadap kinerja keuangan LPD di Kabupaten Klungkung. Penelitian ini bertolak belakang dengan penelitian yang dilakukan oleh Mahaendrayasa \& Putri (2017) yang menghasilkan hasil transparansi berpengaruh positif dan tidak signifikan terhadap kinerja keuangan LPD di Kota Denpasar.

Hasil penelitian ini sesuai dengan teori keagenan dimana agen umumnya memiliki informasi yang lebih banyak tentang perusahaan dibandingkan prinsipal. Untuk menghindari terjadinya asimetri informasi, maka perusahaan perlu transparan terhadap informasi perusahaan. Keterbukaan informasi kepada pihak yang berkepentingan akan menambah kepercayaan prinsipal sehingga dapat meningkatkan kinerja keuangan.

Penelitian ini memberikan hasil bahwa akuntabilitas berpengaruh positif pada kinerja keuangan LPD di Kecamatan Kuta Utara, Kuta dan Kuta Selatan. Artinya, semakin jelas struktur, fungsi dan wewenang pelaksanaan dalam LPD maka semakin meningkat pula kinerja keuangan LPD.

Akuntabilitas yaitu kejelasan fungsi, pelaksanaan dan pertanggungjawaban organ perusahaan sehingga pegelolaan perusahaan berjalan secara efektif. Perusahaan yang dapat mempertanggungjawabkan kinerjanya secara wajar dan transparan maka dalam pengelolaan perusahaan akan dapat mencegah adanya tindakan penyalahgunaan wewenang dalam perusahaan sehingga akan menumbuhkan kepercayaan stakeholder. Dalam penelitian Andreana \& Wirajaya (2018), semakin jelas tanggungjawab struktur organisasi dalam perusahaan, maka operasional perusahaan semakin terarah sehingga kinerja keuangan semakin meningkat.

Berdasarkan penelitian Sandraningsih \& Putri (2015) yang menyatakan bahwa akuntabilitas berpengaruh positif dan signifikan terhadap kinerja keuangan LPD Kecamatan Abiansemal Kabupaten Badung. Hal tersebut juga 
terjadi pada penelitian Andreana \& Wirajaya (2018), akuntabilitas berpengaruh positif dan signifikan terhadap kinerja keuangan LPD di Kabupaten Klungkung.

Hasil penelitian ini sesuai dengan teori keagenan dimana agen dan prinsipal mempunyai kepentingan yang berbeda. Dengan demikian hubungan prinsipal dan agen memberi konsekuensi, bahwa agen berkewajiban mempertanggungjawabkan apa yang telah diamalkan oleh prinsipal. Agen dapat akuntabel kepada principal dan principal harus mampu memberi tugas, wewenang secara jelas dan memperhatikan hak agen. Maka dari itu agen akan mampu melaksanakan tugas dengan baik, sehingga akan menghasilkan kinerja keuangan yang baik.

Penelitian ini memberikan hasil bahwa responsibilitas berpengaruh positif pada kinerja keuangan LPD di Kecamatan Kuta Utara, Kuta dan Kuta Selatan. Artinya, semakin patuh LPD terhadap peraturan yang berlaku serta melaksanakan tanggungjawab atas LPD maka semakin meningkat pula kinerja keuangan LPD.

Prinsip responsibilitas menekankan perusahaan harus berpegang pada hukum yang berlaku dan dapat mempertanggungjawabkan semua kegiatan perusahaan pada stakeholder dan masyarakat. Dalam penelitian Sandraningsih \& Putri (2015) untuk mendapatkan kepercayaan masyarakat dan lingkungan, terlebih dahulu perusahaan harus mentaati peraturan perundang-undangan. Apabila perusahaan patuh terhadap peraturan dan melaksanakan tanggungjawab kepada stakeholder, maka kinerja keuangan perusahaan akan meningkat.

Berdasarkan penelitian Sandraningsih \& Putri (2015) yang menyatakan bahwa responsibilitas berpengaruh positif dan signifikan terhadap kinerja keuangan LPD Kecamatan Abiansemal Kabupaten Badung. Hal tersebut juga terjadi pada penelitian Andreana \& Wirajaya (2018), responsibilitas berpengaruh positif dan signifikan terhadap kinerja keuangan LPD di Kabupaten Klungkung. Penelitian ini bertolak belakang dengan penelitian yang dilakukan oleh Mahaendrayasa \& Putri (2017) yang menghasilkan hasil responsibilitas berpengaruh positif dan tidak signifikan terhadap kinerja keuangan LPD di Kota Denpasar.

Sejalan dengan teori stewardship, yang menggambarkan para manajer tidak termotivasi oleh tujuan-tujuan individu tetapi lebih merujuk kepada sasaran hasil utama demi kepentingan organisasi (Riyadi \& Yulianto, 2014). Maka agen dapat bertindak sesuai dengan keinginan prinsipal untuk mencapai tujuan organisasi, sehingga dikatakan bahwa agen mematuhi dan bertanggungjawab atas peraturan undang-undang yang berlaku demi mencapai tujuan bersama, maka dari itu akan meningkatkan kinerja keuangan.

Penelitian ini memberikan hasil bahwa independensi berpengaruh positif pada kinerja keuangan LPD di Kecamatan Kuta Utara, Kuta dan Kuta Selatan. Artinya, semakin independen dalam mengelola LPD maka semakin meningkat pula kinerja keuangan LPD.

Prinsip independensi artinya bebas atau kemandirian, keputusan yang diambil manajemen harus secara independen yang dalam hal ini berarti keputusan manajemen tidak terikat oleh pihak manapun tanpa terkecuali (Sandraningsih \& Putri, 2015). Perusahaan harus mampu menghindari terjadinya 
dominasi oleh pihak tertentu, bebas dari benturan kepentingan dan dari segala pengaruh atau tekanan, sehingga pengambilan keputusan dapat dilakukan secara objektif. Dengan tidak adanya benturan kepentingan dalam pengelolaan perusahaan maka dapat berdampak pada meningkatnya kepercayaan prinsipal, sehingga kinerja keuangan akan meningkat.

Berdasarkan penelitian Sandraningsih \& Putri (2015) yang menyatakan bahwa independensi berpengaruh positif dan signifikan terhadap kinerja keuangan LPD Kecamatan Abiansemal Kabupaten Badung. Hal tersebut juga terjadi pada penelitian Andreana \& Wirajaya (2018), independensi berpengaruh positif dan signifikan terhadap kinerja keuangan LPD di Kabupaten Klungkung. Penelitian ini bertolak belakang dengan penelitian yang dilakukan oleh Sastra \& Erawati (2017) yang menghasilkan hasil independensi berpengaruh negatif dan tidak signifikan terhadap kinerja keuangan LPD.

Sejalan dengan teori keagenan, perbedaan kepentingan antara agen dan prinsipal akan menimbulkan adanya asimetri informasi. Hal ini dapat diminimalisir jika agen independen terhadap tanggungjawabnya dengan tidak mudah terpengaruh oleh pihak lain. Hal ini akan menyebabkan perusahaan terhindar dari pihak-pihak yang dapat merugikan perusahaan, sehingga kinerja keuangan perusahaan semakin baik.

Penelitian ini memberikan hasil bahwa kewajaran berpengaruh positif pada kinerja keuangan LPD di Kecamatan Kuta Utara, Kuta dan Kuta Selatan. Artinya, semakin adil dan setara dalam memenuhi hak prinsipal maka semakin meningkat pula kinerja keuangan LPD.

Perusahaan dalam melakukan kegiatannya harus senantiasa memperhatikan kepentingan pemangku kepentingan lainnya berdasarkan prinsip kesetaraan dan kewajaran (Devi \& Ratnadi, 2018). Kewajaran dapat pula diartikan sebagai keadilan perusahaan dalam memenuhi kepentingan stakeholders berdasarkan undang-undang yang berlaku (Sandraningsih dan Putri, 2015). Jika dalam mengelola usahanya perusahaan memperhatikan hak-hak stakeholder dengan asas kewajaran dan kesetaraan, maka akan meningkatkan nilai perusahaan dan kinerja keuangan perusahaan.

Berdasarkan penelitian Sandraningsih \& Putri (2015) yang menyatakan bahwa kewajaran berpengaruh positif dan signifikan terhadap kinerja keuangan LPD Kecamatan Abiansemal Kabupaten Badung. Hal tersebut juga terjadi pada penelitian Andreana \& Wirajaya (2018), kewajaran berpengaruh positif dan signifikan terhadap kinerja keuangan LPD di Kabupaten Klungkung. Penelitian ini bertolak belakang dengan penelitian yang dilakukan oleh Sastra \& Erawati (2017) yang menghasilkan hasil kewajaran berpengaruh positif dan tidak signifikan terhadap kinerja keuangan LPD.

Sejalan dengan teori keagenan, prinsipal sebagai pemilik akan memberi perintah kepada agen, dalam hal ini prinsipal harus mampu memperlakukan agen dengan setara dan wajar agar agen menyampaikan informasi perusahaan secara benar dan sesuai dengan kondisi perusahaan sehingga tidak terjadi asimetri informasi. Sehingga dapat meningkatkan kepercayaan principal dan kinerja keuangan pun akan meningkat. 


\section{SIMPULAN}

Berdasarkan pemaparan dapat dinyatakan bahwa transparansi secara signifikan berpengaruh positif dengan kinerja keuangan. Hasil tersebut mengimplikasikan bahwa agar kinerja keuangan meningkat maka pihak manajemen perusahaan hendaknya meningkatkan transparansi yang sesuai dengan lingkungan kerja serta keuntungan yang diperoleh perusahaan. Selain itu, pihak manajemen hendaknya memberikan pelatihan kepada karyawan dengan begitu kinerja keuangan akan meningkat.

Akuntabilitas secara signifikan berpengaruh positif dengan kinerja keuangan. Hal tersebut berimplikasi bahawa untuk meningkatkan kinerja keuangan pihak manajemen perusahaan hendaknya memberikan semangat serta masukan agar dapat memotivasi karyawan. Selain itu, pihak manajemen perusahaan hendaknya tidak memberikan tanggung jawab yang tidak sesuai dengan jabatan serta deskripsi pekerjaan yang diemban karyawan.

Selain itu, responsibilitas secara signifikan berpengaruh positif dengan kinerja keuangan. Hasil tersebut mengimplikasikan bahwa pihak manajemen hendaknya mengkondisikan agar dalam rekrutmen pegawai diperhatikan responsibilitas setiap calon karyawan. Independensi karyawan perlu ditingkatkan dengan pemberian pelatihan serta kewajaran dalam bersikap dalam proses kinerja perlu diperhatikan sehingga kinerja keuangan meningkat.

Berdasarkan pemaparan di atas, maka dalam penelitian ini masih terdapat beberapa keterbatasan. Pertama, sampel yang dipakai perlu ditingkatkan. Hal tersebut dilakukan bahwa agar hasil yang didapat dapat menggambarkan keadaan dilapangan secara holistik. Kedua, kontruksi variabel yang digunakan pada model penelitian sederhana. Hal tersebut kedepannya dapat ditanggulangi dengan cara menambah kontruksi variabel dalam bentuk variabel mediasi maupun moderasi.

\section{REFERENSI}

Andreana, M. O. C., \& Wirajaya, I. G. A. (2018). Pengaruh Transparancy, Accountability, Responsibility, Independency, dan Fairness Pada Kinerja Keuangan Lembaga Perkreditan Desa. E-Jurnal Akuntansi Universitas Udayana, 23, 1305. https://doi.org/10.24843/eja.2018.v23.i02.p19

Astawa, I. P., Sukawati, T. G. R., Triyuni, N. N., \& Abdi, I. N. (2016). Performance of Microfinance Institution in Harmony Cultural Perspective in Bali. Procedia - Social and Behavioral Sciences. https://doi.org/10.1016/j.sbspro.2016.04.051

Bistrova, J., \& Lace, N. (2012). Corporate Governance Influence on Firms' Financial Performance in CEE Countries. 11-16. https:// doi.org/10.3846/bm.2012.002

Devi, K. T. W., \& Ratnadi, N. M. D. (2018). Pengaruh Prinsip-Prinsip Good Corporate Governance Pada Kualitas Informasi Keuangan Pdam Kabupaten Buleleng. E-Jurnal Akuntansi Universitas Udayana, 23(3), 2311-2334. https:// doi.org/10.24843/ eja.2018.v23.i03.p26

El-Chaarani, H. (2014). The Impact of Corporate Governance on the Performance of Lebanese Banks. The International Journal of Business and Finance Research, $8(5), 35-46$.

Gayatri, I. A. S., \& Suputra, I. D. G. D. (2013). Pengaruh Corporate Governance, Ukuran Perusahaan Dan Leverage Terhadap Integritas Laporan Keuangan. 
E-Jurnal Akuntansi Universitas Udayana, 5(2), 345-360.

Gupta, V. K., Mortal, S., Chakrabarty, B., Guo, X., \& Turban, D. B. (2019). CFO Gender and Financial Statement Irregularities. Academy of Management Journal. https:/ / doi.org/10.5465/amj.2017.0713

Hart, O. (1995). Corporate Governance: Some Theory and Implications. The Economic Journal, 105(430), 678. https:/ / doi.org/10.2307/2235027

Hindistari, R. R., \& Putri, I. G. A. M. A. D. (2016). Pengaruh Penerapan PrinsipPrinsip Good Corporate Governance Pada Kinerja Bank Perkreditan Rakyat Kabupaten Gianyar. E-Jurnal Akuntansi Universitas Udayana, 16(1), 101-128.

Jensen, M. C., \& Meckling, W. H. (1976). Theory of the Firm: Managerial Behavior, Agency Costs And Ownership Structure. Journal of Financial Economics, 3, 305-360. https://doi.org/http://dx.doi.org/10.1016/0304405X(76)90026-X

Khika Indira Putri Hermawan Korompis, \& Wirajaya, I. G. A. (2017). Pengaruh Kinerja Keuangan Pada Nilai Perusahaan dengan Good Corporate Governance Sebagai Variabel Pemoderasi. E-Jurnal Akuntansi Universitas Udayana, 21(1), 1-28.

Mahaendrayasa, P. K. A., \& Putri, I. G. A. M. A. D. (2017). Pengaruh PrinsipPrinsip Good Corporate Governance Terhadap Kinerja Keuangan Lembaga Perkreditan Desa (LPD) Di Kota Denpasar. E-Jurnal Akuntansi Universitas Udayana, 21(2), 970-995.

Mandala, I. G. N. N., Nawangpalupi, C. B., \& Praktikto, F. R. (2012). Assessing Credit Risk: An Application of Data Mining in a Rural Bank. Procedia Economics and Finance. https:/ / doi.org/10.1016/s2212-5671(12)00355-3

Muliartha RM, K. (2020). Peran Moderasi Indeks Pembangunan Manusia Pada Hubungan Resiko Kredit Dan Resiko Likuiditas, Total Aset Dengan Kinerja Keuangan Lembaga Perkreditan Desa (LPD). Jurnal Ilmiah Akuntansi Dan Bisnis, 15(2), 252-267. https:/ / doi.org/10.24843/jiab.2020.v15.i02.p08

Rambo, C. M. (2013). Influence of The Capital Markets Authority's Corporate Governance Guidelines on Financial Performance of Commercial Banks in Kenya. The International Journal of Business and Finance Research, 7(3), 77-93.

Riyadi, S., \& Yulianto, A. (2014). Pengaruh Pembiayaan Bagi Hasil, Pembiayaan Jual Beli, Financing To Deposit Ratio (Fdr) Dan Non Performing Financing (Npf) Terhadap Profitabilitas Bank Umum Syariah Di Indonesia. Accounting Analysis Journal, 3(4), 466-474. https:// doi.org/10.15294/aaj.v3i4.4208

Sandraningsih, N. K. B., \& Putri, I. G. A. M. A. D. (2015). Pengaruh PrinsipPrinsip Good Corporate Governance Pada Kinerja Keuangan Lembaga Perkreditan Desa Kecamatan Abiansemal. E-Jurnal Akuntansi Universitas Udayana, 11(3), 878-893.

Sastra, I. M. B., \& Erawati, N. M. A. (2017). Pengaruh Penerapan Prinsip-Prinsip Good Corporate Governance Dan Budaya Tri Hita Karana Pada Kinerja Keuangan. E-Jurnal Akuntansi Universitas Udayana, 19(1), 421-451.

Setyawan, K. M., \& Putri, I. G. A. M. A. D. (2013). Pengaruh Good Corporate Governance Terhadap Kinerja Keuangan Lembaga Perkreditan Desa di Kecamatan Mengwi Kabupaten Badung. E-Jurnal Akuntansi Universitas Udayana, 5(3), 586-598. 